\title{
Benign Transient Hyperphosphatasemia
}

ISSN: 2576-9200

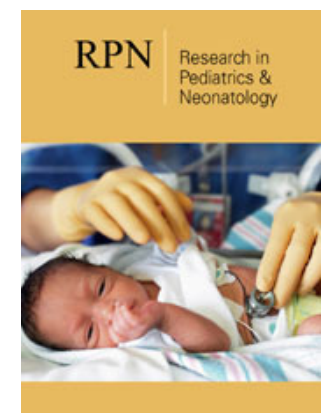

*Corresponding author: David F Crudo, Department of Pediatrics Section on Pediatric Endocrinology, Wake Forest University School of Medicine, USA

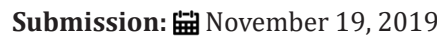

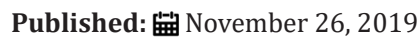

Volume 4 - Issue 1

How to cite this article: Crudo D, Linton J, Sebesta M. Benign Transient Hyperphosphatasemia.Research Article, Res Pediatr Neonatol. 4(1). RPN.000578.2019.

DOI: $10.31031 /$ RPN.2019.04.000578

Copyright $\odot$ David F Crudo

This article is distributed under the terms of the Creative Commons Attribution 4.0 International License, which permits unrestricted use and redistribution provided that the original author and source are credited.

\section{Crudo $\mathrm{DF}^{1 *}$, Linton JM² and Sebesta $\mathrm{MR}^{2}$}

${ }^{1}$ Department of Pediatrics Section on Pediatric Endocrinology, Wake Forest University, USA

${ }^{2}$ Department of Pediatrics Section on General Pediatrics, Adolescent Medicine, and Rheumatology, Wake Forest University, USA

\section{Abstract}

Benign transient hyperphosphatasemia is an idiopathic condition characterized by a temporary elevation of alkaline phosphatase of up to 5 times greater than the upper limit of normal in the absence of bone or hepatobiliary disease. It is typically seen in young pediatric patients and is without an exact etiology. Extensive evaluation of the increased alkaline phosphatase levels can be costly. A "wait and see" approach using minimal further testing can avoid unnecessary costly and potentially harmful diagnostic evaluations.

\section{Introduction}

Alkaline Phosphatase (ALP) is a group of four isoenzymes originating in various tissues such as bone, liver, intestine, kidney, and placenta. Serum levels vary throughout life with levels higher in childhood than in adult, especially during the pubertal bone growth spurt. Hyperphosphatasemia can result from physiologic conditions such as puberty and pregnancy, in pathological conditions of bone and the hepatobiliary tract, and in an idiopathic condition known as benign transient hyperphosphatasemia (BTH). The diagnosis of BTH was first described by Bach et al. [1] and in 1985 Kraut et al. [2]defined the diagnostic criteria for this entity as: age of presentation less than five years; no other evidence for bone or liver disease on physical examination or laboratory findings; elevation in both bone and liver ALP isoenzymes; and a return to normal serum ALP values within four months. BTH is accepted as a harmless self-limiting biochemical disorder without sequelae. The aim of this paper is to report a series of BTH cases and to call attention to this condition and the proposed evaluation guidelines to avoid unnecessary costly testing.

Cases

\section{Patient-1}

4-month-old female infant who presented with a four-day history of emesis without associated fever or diarrhea. Laboratory evaluation showed a markedly elevated ALP of $2700 \mathrm{U} / \mathrm{L}$. Other studies to include liver transaminases, gamma-glutamyl transferase (GGT), calcium, phosphorus, parathyroid hormone (PTH), and 25-hydroxyvitamin D were normal. Alkaline phosphatase isoenzymes showed $32 \%$ hepatic and $68 \%$ bone. Follow-up ALP levels showed a decline to $1248 \mathrm{U} / \mathrm{L}$ after 2 weeks and a return to normal at $235 \mathrm{U} / \mathrm{L}$ after 8 weeks.

\section{Patient-2}

2 year and 3-month-old male who was undergoing an evaluation by Pediatric Neurology for hypotonia and developmental delays. His laboratory evaluation was normal with exception of an elevated ALP of 1145 U/L. He was otherwise healthy, and his parents did not recall a recent preceding illness. Further evaluation showed normal levels of liver transaminases, GGT, calcium, phosphorus, and PTH. His 25-hydroxyvitamin D level was insufficient at 18ng/ $\mathrm{ml}$. Alkaline phosphatase isoenzymes showed 39\% hepatic, $57 \%$ bone, and $4 \%$ intestinal. The follow-up ALP level obtained after eight weeks was normal at $197 \mathrm{U} / \mathrm{L}$.

\section{Patient-3}

14-month-old female who was evaluated for recent weight loss. She had a history of a gastrointestinal viral illness several months earlier and had been treated for ongoing ear infections for several months. Laboratory evaluation was normal with the 
exception of an elevated ALP of 3863 U/L. Additional studies to include liver transaminases, GGT, calcium, phosphorus, PTH, and 25-hydroxyvitamin D were normal. Alkaline phosphatase isoenzymes showed $29 \%$ hepatic, $59 \%$ bone, and $6 \%$ intestinal. The ALP level declined to $736 \mathrm{U} / \mathrm{L}$ in two weeks and returned to normal at $186 \mathrm{U} / \mathrm{L}$ after eight weeks.

\section{Patient-4}

4 year and 9-month-old male who had complained of abdominal pain for the past 2-3 months, typically occurring several hours after dinner nearly every night as well as throughout the day. He had some nausea and diarrhea, but no emesis or weight loss. His chemistry evaluation was normal with the exception of an elevated ALP of 1658 U/L. Further studies showed normal levels of liver transaminases, calcium, phosphorus, and PTH. His 25 -hydroxyvitamin D level was mildly low at $28.7 \mathrm{ng} / \mathrm{ml}$. Alkaline phosphatase isoenzymes showed $43 \%$ hepatic, and $57 \%$ bone. The ALP level obtained ten days later had decreased to $553 \mathrm{U} / \mathrm{L}$ and was normal at $163 \mathrm{U} / \mathrm{L}$ after six weeks.

\section{Patient-5}

2 year and 1-month-old female who presented for evaluation of fatigue and possible neck pain. She had a history of recent nasal congestion, but was without fever, emesis, diarrhea, shortness of breath or focal weaknesses. Laboratory evaluation was normal with the exception of an elevated ALP of $1401 \mathrm{U} /$ L. Other studies showed normal levels of calcium, phosphorus, and liver transaminases. Her 25 -hydroxyvitamin D level was mildly low at $21 \mathrm{ng} / \mathrm{ml}$. Alkaline phosphatase isoenzymes were not obtained due to sample hemolysis. Repeat ALP level in one month was normal at $192 \mathrm{U} / \mathrm{L}$.

\section{Patient-6}

15-month-old female who presented with an 8-month history of an enlarged posterior cervical lymph node. Eight days prior to presentation, she had a tactile fever, rhinorrhea and fussiness that resolved after 3 days. She had no weight loss, fatigue, decrease in appetite, emesis or diarrhea. A complete blood count, erythrocyte sedimentation rate, and C-reactive protein were normal. Chemistry studies were normal with the exception of a markedly elevated ALP of $3084 \mathrm{U} / \mathrm{L}$. Liver transaminases, GGT, calcium, phosphorus, and PTH levels were normal. Her 25-hydroxyvitamin D level was mildly low at $24 \mathrm{ng} / \mathrm{ml}$. ALP isoenzymes were $37 \%$ liver and $63 \%$ bone. Two weeks later ALP had decreased to $1196 \mathrm{U} / \mathrm{L}$ and after another four months it normalized to $217 \mathrm{U} / \mathrm{L}$. Patient demographics and laboratory values are summarized in Table 1.

Table 1: Demographics and laboratory values.

\begin{tabular}{|c|c|c|c|c|c|c|c|c|c|c|}
\hline Patient & $\begin{array}{c}\text { Age at } \\
\text { Diagnosis }\end{array}$ & Sex & $\begin{array}{c}\mathrm{Ca} \\
\mathrm{mg} / \mathrm{dl} \\
(8.5-10.5)\end{array}$ & $\begin{array}{c}P \\
\mathrm{mg} / \mathrm{dl} \\
(3.5-6.0)\end{array}$ & $\begin{array}{c}\text { PTH } \\
\mathrm{pg} / \mathrm{ml} \\
(12-72)\end{array}$ & $\begin{array}{c}\text { GGT } \\
\text { U/L } \\
(0-20)\end{array}$ & $\begin{array}{c}25-\mathrm{OH} \text { D } \\
\mathrm{ng} / \mathrm{ml} \\
(30-100)\end{array}$ & $\begin{array}{c}\text { ALP } \\
\text { U/L } \\
(150-450)\end{array}$ & $\begin{array}{c}\text { ALP } \\
\text { Iso-enzymes }\end{array}$ & $\begin{array}{l}\text { Time to ALP } \\
\text { Normalization }\end{array}$ \\
\hline 1 & 4 months & $\mathrm{F}$ & 9.9 & 6.1 & 20 & 15 & 41 & 2700 & $\begin{array}{l}32 \% \text { liver } \\
62 \% \text { bone }\end{array}$ & 8 weeks \\
\hline 2 & $\begin{array}{l}2 \text { year } 3 \\
\text { months }\end{array}$ & M & 9.5 & 4.5 & 15 & 9 & 18 & 1145 & $\begin{array}{l}39 \% \text { liver } \\
57 \% \text { bone }\end{array}$ & 8 weeks \\
\hline 3 & 14 months & $\mathrm{F}$ & 9.9 & 5.1 & 25 & 6 & 30 & 3863 & $\begin{array}{l}29 \% \text { liver } \\
65 \% \text { bone }\end{array}$ & 8 weeks \\
\hline 4 & $\begin{array}{l}4 \text { years } 9 \\
\text { months }\end{array}$ & M & 9.5 & 4.6 & 22 & TND & 28.7 & 1658 & $\begin{array}{l}47 \% \text { liver } \\
53 \% \text { bone }\end{array}$ & 6 weeks \\
\hline 5 & $\begin{array}{c}2 \text { years } 1 \\
\text { months }\end{array}$ & $\mathrm{F}$ & 10.3 & 5.6 & TND & TND & 21 & 1401 & TND & 1 month \\
\hline 6 & 15 months & $\mathrm{F}$ & 9.6 & 5 & 24 & 7 & 24 & 3084 & $\begin{array}{l}37 \% \text { liver } \\
63 \% \text { bone }\end{array}$ & 4 months \\
\hline
\end{tabular}

F: female, M: male, Ca: calcium, P: Phosphorus, TND: test not done, PTH: parathyroid hormone, GGT: gamma-glutamyl transferase, ALP: Alkaline Phosphatase.

\section{Discussion}

Transient benign hyperphosphatasemia as first described by Bach is characterized by a temporary elevation of alkaline phosphatase of up to 5 times greater than the upper limit of normal in the absence of bone or hepatobiliary disease [1,3]. A recent review of 116 publications on TBH found that the age of presentation ranged from 2 months to 17 years with a median of 18 months [4]. There was no predilection for either gender or ethnicity $[4,5]$. A prospective study of 316 children in Boston estimated the prevalence of TBH to be approximately $2.8 \%$; however, this is felt to be an underestimation [5]. The exact etiology of TBH is currently unknown [6]. An association with preceding infection, such as viral upper respiratory infection, viral gastroenteritis, urinary tract infection or otitis media has been proposed given some evidence of a seasonal predilection and case reports of multiple siblings with infectious symptoms and transiently elevated ALP [7,8]. However, no studies have been able to identify a direct causal link between an infectious agent and TBH $[4,5]$. It is possible that patients with infectious symptoms are more likely to undergo a laboratory evaluation and elevated ALP is simply an incidental finding [4]. It is hypothesized that an inhibition of ALP clearance is responsible for the transient elevation however this has only been documented in animal models [6]. 
Measurement of ALP isoenzymes in the setting of TBH has been consistent with a bone origin, hepatic origin, intestinal origin or a combination [2,4]. Measurement of 25-hydroxyvitamin D, PTH, calcium, magnesium and phosphorous were not significantly different in patients with normal, intermediate or high ALP levels [5]. In TBH, ALP typically normalizes within 4 months; however, there have been case reports of it taking up to 4 years [4]. Since TBH is relatively common, harmless, and transient, a "Wait and See" approach can avoid costly and potentially harmful diagnostic evaluations [9]. A "Wait and See" evaluation includes ALPisoenzymes, GGT, calcium, phosphorous, parathyroid hormone, 25-hydroxyvitamin D, blood urea nitrogen, and creatinine. If elevated ALP is the only abnormality, the history does not support metabolic bone disease, liver or kidney dysfunction, and the patient is not taking medications known to elevate ALP, then primary care providers can simply recheck ALP in 4 months. If there is any concern on history, exam or laboratory evaluation, then patients should be evaluated by the appropriate specialists, such as endocrinology, gastroenterology or nephrology.

\section{References}

1. Bach UD (1954) The behavior of alkaline serum phosphatase in premature babies, rickets and spasmophiles. Journal of Pedaitrics 74(6): 593-609.
2. Kraut JR, Metrick M, Maxwell NR, Kaplan MM (1985) Isoenzyme studies in transient hyperphosphatasemia of infancy. Ten new cases and review of the literature. Am J Dis Child 139(7): 736-740.

3. Corathers SD (2006) Focus on diagnosis: the alkaline phosphatase level: nuances of a familiar test. Pediatr Rev 27(10): 382-384.

4. Gualco G, Lava SAG, Garzoni L, Simonetti GD, Bettinelli A, et al. (2013) Transient benign hyperphosphatasemia. J Pediatr Gastroenterol Nutr 57(2): 167-171.

5. Huh SY, Feldman HA, Coz JE, Gordon CM (2009) Prevalence of transient hyperphosphatasemia among healthy infants and toddlers. Pediatrics 124(2): 703-709.

6. Stein P, Rosalki SB, Foo AY, Hjeim M (1987) Transient hyperphosphatasemia of infancy and early childhood: clinical and biochemical features of 21 cases and literature review. Clin Chem 33(2 Pt 1): 313-318.

7. Behúlová D, Bzdúch V, Holesová D, Vasilenková A, Ponec J (2000) Transient hyperphosphatasemia of infancy and childhood: Study of 194 Cases. Clin Chem 46(11): 1868-1869.

8. Kruse K, Kurz N (1989) Further evidence for infectious origin of isolated transient hyperphosphatasaemia. Eur J Pediatr 148(5): 453-454.

9. Otero JL, González Peralta RP, Andres JM, Jolley CD, Novak DA, et al. (2011) Elevated alkaline phosphatase in children: An algorithm to determine when a "wait and see" approach is optimal. Clin Med Insights Pediatr 5: 15-18. 